\title{
MENINGKATKAN AKTIVITAS DAN HASIL BELAJAR KIMIA MELALUI E-LEARNING BERBASIS GOOGLE CLASSROOM
}

\section{IMPROVING CHEMISTRY LEARNING ACTIVITIES AND OUTCOMES THROUGH GOOGLE CLASSROOM BASED E-LEARNING}

\begin{abstract}
ANSAR SUMA
SMAN 7 Bulukumba

\section{Received: March 03, 2021 \\ Revised: March 06, 2021 \\ Accepted: March 10, 2021}

Abstract

During the Covid-19 pandemic, chemistry learning was less than the maximum, which was characterized by low student activity and learning outcomes. This action research is conducted in two cycles, aiming to improve the activity and results of chemistry learning through Google Classroom-based e-Learning. The research procedure used the model kemmis and Mc. Taggart and was conducted on class XII MIA1 students numbering 25 people. Data collection of activities and learning outcomes using questionnaires and test learning results. Observations made at the end of each cycle, it was obtained that, student activity increased from an average of $43,56 \%$ before the action to $62,09 \%$ in cycle I, and an average of $82,31 \%$ in cycle II. Student learning outcomes increased from an average of 67,20 before the action, to 72,60 in cycle I and an average of 81,20 in cycle II. These results show that: the application of Google Classroom-based e-learning can improve the activity and results of chemistry learning.
\end{abstract}

\begin{abstract}
Abstrak
Selama masa Pandemi Covid-19, pembelajaran kimia berlangsung kurang maksimal yang ditandai dengan rendahnya aktivitas dan hasil belajar murid. Penelitian tindakan ini dilakukan di dua siklus, bertujuan untuk meningkatkan aktivitas dan hasil belajar kimia dengan e-learning menggunakan Google Classroom. Prosedur penelitian menggunakan model Kemmis dan Mc. Taggart dan dilakukan pada murid kelas XII MIA1 yang berjumlah 25 orang. Pengumpulan data aktivitas dan hasil belajar menggunakan angket dan tes hasil belajar. Observasi yang dilakukan di akhir setiap siklus, didapatkan bahwa, aktivitas murid mengalami peningkatan dari rerata 43,56\% sebelum tindakan menjadi $62,09 \%$ di siklus I, dan rerata $82,31 \%$ pada siklus II. Hasil belajar murid meningkat dari rerata 67,20 sebelum tindakan, menjadi 72,60 pada siklus I dan rerata 81,20 di siklus II. Hasil itu memperlihatkan bahwa: penerapan e-learning menggunakan google classroom dapat mengoptimalkan aktivitas dan hasil belajar kimia.
\end{abstract}

Keywords: e-learning, google classroom, and student activities

Kata kunci: $\quad$ e-learning, google classroom, dan aktivitas murid

$\left(^{*}\right)$ Corresponding Author: anchasuma@gmail.com

How to Cite: Suma, A. (2021). Meningkatkan aktivitas dan hasil belajar kimia melalui e-learning berbasis google classroom. Jurnal Lingkar Mutu Pendidikan, 18 (1), 1-12. https://doi.org/10.54124/jlmp.v18i1.22

\section{PENDAHULUAN}

Perubahan perilaku masyarakat dalam masa yang relatif lama termasuk di dunia pendidikan yang menghadirkan pembelajaran jarak jauh (PJJ) merupakan bagian dari akibat semakin memburuknya keadaan karena meluasnya infeksi Covid-19 yang menjadikan hampir semua sektor kehidupan terkena dampaknya.

Perubahan yang terjadi pada perilaku masyarakat pada masa pandemi seperti bekerja dari rumah dan penggunaan teknologi yang sebelumnya hanya pendukung ataupun hanya sebagai kebutuhan rekreasi, sekarang berubah menjadi fasilitas bagi pekerja yang bersifat primer (Roycnhansyah, 2020). Pembelajaran yang dilakukan secara langsung dengan tatap muka di kelas selama ini sekarang harus mengalami pembelajaran jarak jauh juga berdampak pada sistem pendidikan di Indonesia.

Surat edaran memdikbud nomor 4 tahun 2020 tentang implementasi pendidikan di masa darurat Covid-19 kementerian pendidikan dan kebudayaan ditetapkan sebagai antisipasi penyebaran 
Covid-19 lingkungan sekolah. Ada tiga poin penting terkait pembelajaran dalam jaringan (daring), adalah: (a) dilakukan dalam rangka memberikan pengalaman belajar yang bermakna, tanpa harus menyelesaikan semua target kurikulum baik untuk kenaikan kelas atau pun kelulusan; (b) difokuskan di pendidikan yang mengarahkan kecakapan hidup; dan (c) adanya pemberian tugas proses belajar mengajar bagi murid dapat bervariasi antarmurid, disesuaikan dengan minat dan kondisi masingmasing, termasuk dengan memikirkan fasilitas belajar yang ada di rumah yang dimiliki murid (Kemdikbud, 2020).

Implementasi proses belajar mengajar daring selama saat pandemi Covid-19 belum berjalan maksimal. Salah satunya di SMAN 7 Bulukumba. Observasi pendahuluan pada sekolah tersebut memperlihatkan bahwa aktivitas murid seperti mengamati demonstrasi guru dan mendengarkan penjelasan guru dengan seksama masih berkategori cukup, sedangkan aktivitas belajar yang lain seperti menyelesaikan kuis daring, mengajukan pertanyaan, menyelesaikan tugas dan mengemukakan pendapat di diskusi daring masih berpredikat kurang. Demikian pula halnya dengan hasil belajar murid yang kurang memuaskan. Khusus di mata pelajaran kimia, hasil belajar masih berkategori kurang, yaitu rerata 67,20 dan ketuntasan klasikal 60\% dari kriteria ketuntasan minimal (KKM) sebesar 75.

Kegiatan belajar adalah sesuatu yang sangat penting dan hanya dapat tercipta jika murid terlibat secara penuh proses belajar mengajar. Aktivitas belajar dapat tercipta apabila murid terlibat belajar secara aktif menggali kompetensi dengan rasa ingin tahunya sehingga interaksi yang berlangsung akan menjadi pengalaman dan keinginan untuk memahami sesuatu yang baru. Aktivitas belajar yang tinggi dapat memperlihatkan bahwa proses belajar mengajar berlangsung dengan efektif dan optimal, sehingga proses belajar mengajar lebih meningkat.

Keaktifan murid dapat diperlihatkan pada keikutsertaan dalam melaksanakan tugasnya, terlibat di pemecahan persoalan, bertanya kepada murid lain atau pendidik, mendapatkan informasi sendiri, berdiskusi dalam kelompok, berlatih memecahkan soal, mengimplementasikan apa yang telah dipahami dalam menyelesaikan tugas. Proses belajar mengajar akan berjalan efektif, kondusif, hangat, menyenangkan, menarik dan nyaman apabila aktivitas itu dapat diaplikasikan di aktivitas belajar mengajar secara optimal, maka proses. Proses belajar mengajar yang berlangsung menjadi tidak membosankan dan di akhir kegiatan akan mengoptimalkan hasil belajar murid.

Hasil belajar adalah bagian terpenting di pembelajaran. Hasil belajar sebagai perubahan tingkah laku setelah murid mengalami proses proses belajar mengajar yang mencakup bidang kognitif, afektif, dan psikomotorik. Ranah kognitif secara spesifik terbagi atas: (a) pengetahuan, berkenaan dengan fakta, peristiwa, pengertian kaidah, teori, prinsip, atau metode; (b) pemahaman adalah kemampuan menyelami makna dari hal yang dipelajari; (c) implementasi adalah kemampuan memperlihatkan metode/kaidah di situasi baru; (d) analisis, adalah kemampuan mengurai persoalan ke dalam bagianbagian kecil sehingga mudah dipahami; (e) sintesis adalah kemampuan membentuk pola baru; dan ( $f$ ) evaluasi, yang meliputi kemampuan membuat pendapat tentang beberapa hal berdasarkan kriteria tertentu.

Hasil belajar sebagai salah satu indikator capaian tujuan proses belajar mengajar dipengaruhi oleh beberapa faktor. Hal yang mempengaruhi hasil belajar, diantaranya adalah: (a) internal adalah faktor yang ada di diri murid, meliputi: kondisi psiologis dan psikologis; (b) eksternal meliputi, faktor lingkungan nonsosial dan sosial dan instrumental yang meliputi: antara lain sarana dan prasarana fisik kelas, alat pembelajaran, media pembelajaran, pendidik, dan kurikulum atau materi pelajaran serta strategi atau model pembelajaran.

Salah satu pendekatan pembelajaran yang bisa dimanfaatkan selama masa pandemi Covid-19 adalah e-learning berbasis Google Classroom. Melalui Google Classroom. Murid bisa melakukan berbagai aktivitas proses belajar mengajar daring dengan bimbingan pendidik. Murid dapat mengunggah materi ajar, memeriksa tugas dan nilai, saling berdiskusi, menyelesaikan soal, serta melakukan tatap maya dengan google meet. Selain itu aplikasi ini dapat dipakai kapan dan dimana pun serta tidak terbatasi oleh waktu dan ruang, disediakan gratis dan tidak pernah digunakan sebagai konten berbayar. Dengan demikian pembelajaran akan lebih efisien, menarik dan menyenangkan murid karena mereka bisa mendapatkan manfaat diantaranya: fleksibilitas, interaksi, dan kecepatan hingga visualisasi yang baik. 
Implementasi e-learning menggunakan Google Classroom diyakini dapat mengoptimalkan aktivitas dan hasil belajar murid. Hal ini diketahui dari beberapa penelitian sebelumnya bahwa pemakaian aplikasi Google Classroom dapat mengoptimalkan keaktifan belajar dan kedisiplinan pengumpulan tugas murid kelas IVB SDN Godean 1 Sleman (Sari, 2020). Penelitian lain di jenjang SMA juga menyimpulkan bahwa hasil belajar di mata pelajaran matematika di kelas X IPS 3 SMA Batik 2 Surakarta dapat ditingkatkan dengan menggunakan aplikasi google classroom (Darmawan, 2019). Demikian pula halnya dengan penelitian di jenjang SMK yang dilakukan yang menyimpulkan bahwa media e-learning memakai Google Classroom dapat mengoptimalkan hasil belajar murid SMK. Hal ini terlihat dari rerata hasil belajar dari 72,9 naik menjadi 85,5 (Su'uga, 2020).

Interaksi yang tinggi antara pendidik dengan murid atau pun dengan antarmurid dapat diakibatkan karena keaktifan murid di proses belajar. Hal ini akan mengakibatkan suasana kelas menjadi segar dan kondusif dimana masing-masing murid dapat mengoptimalkan kemampuannya semaksimal mungkin. Aktivitas yang timbul dari murid akan mengakibatkan pula terciptanya pengetahuan dan keterampilan yang akan mengarah di peningkatan hasil belajar murid.

Dari latar belakang yang telah disampaikan maka penting untuk mengimplementasikan e-learning menggunakan Google Classroom di proses belajar mengajar untuk mengoptimalkan aktivitas dan hasil belajar kimia di SMAN 7 Bulukumba. Hal itu juga diinginkan bisa menjadi solusi proses belajar mengajar di kelas yang tidak dapat dilakukan secara tatap muka di tengah pandemi Covid-19.

\section{METODE PENELITIAN}

Penelitian ini menggunakan rancangan tindakan kelas (action research) dengan mengarah pada model Kemmis, Mc. Taggart, dan Nixon (Stephen Kemmis, 2013). Penelitian ini dilakukan dua siklus dan berlangsung pada Juli sampai dengan Oktober 2020 di SMAN 7 Bulukumba yang beralamat di jalan H. Allu No 121A Bontosunggu kabupaten Bulukumba, Sulawesi Selatan. Sasaran kegiatan ini adalah murid kelas XII MIA 1 sebanyak 25 orang, terdiri dari 8 putra dan 17 putri dengan kompotensi akademik yang berbeda.

Tahapan tindakan yang akan dilakukan digambarkan pada skema seperti di Gambar 1.

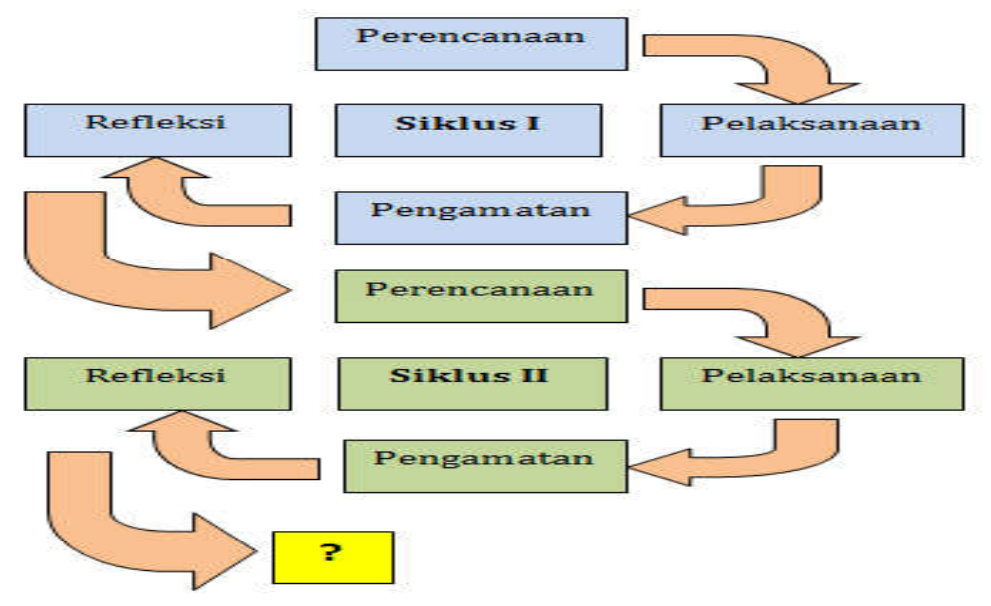

Gambar 1. Bagan skema penelitian (sumber: Suharsimi Arikunto, 2012)

Pada Siklus I perencanaan yang dilakukan meliputi: mengajukan izin kepada kepala sekolah, menyusun jadwal penelitian dengan memperhatikan waktu yang tersedia, membuat rencana pelaksanaan pembelajaran (RPP), menyiapkan dan mengunggah infografis, modul, dan video pembelajaran. Selain itu juga dipersiapkan LKS, kuis daring, tutorial belajar menggunakan Google Classroom, angket aktivitas belajar, instrumen tes hasil belajar, menetapkan fokus observasi, dan aspek yang diamati. Tidak lupa menentukan pelaku observasi, alat bantu observasi dan cara implementasinya, serta menetapkan cara implementasi dan pelaku refleksi.

Implementasi tindakan adalah melakukan proses belajar mengajar memakai Google Classroom sebagaimana yang terlihat di Tabel 1 . 
Tabel 1. Langkah-langkah kegiatan pembelajaran

\begin{tabular}{lll}
\hline No & Tahapan Pembelajaran & \multicolumn{1}{c}{ Kegiatan Pembelajaran } \\
\hline 1 & \multirow{2}{*}{ Pendahuluan } & $\begin{array}{l}\text { Guru membuka pelajaran, mengucapkan salam dan berdoa (daring } \\
\text { sinkron). }\end{array}$ \\
& & Fase 1: penyajian masalah (daring sinkron) \\
& Fase 2: mengorganisasikan murid untuk belajar (daring sinkron) \\
& & Fase 3: membimbing penyelidikan untuk pengumpulan data (daring \\
& & asinkron) \\
& Fase 4: penyajian hasil \\
& Fase 5: refleksi dan mengevaluasi proses pemecahan masalah \\
& & (daring sinkron) \\
& & Melalui aplikasi google meet guru membantu murid untuk \\
& & membuat kesimpulan \\
\hline
\end{tabular}

Observasi dilakukan untuk mendokumentasikan pengaruh tindakan dan prosesnya. Adapun halhal yang diamati adalah aktivitas belajar yang terdiri dari: (a) observasi demontrasi pendidik; (b) menyelesaikan kuis secara online; (c) mengajukan pertanyaan secara online; (d) menyimak penjelasan pendidik dengan baik; (e) menyelesaikan tugas secara online; $(f)$ mengirimkan tugas secara online; dan (g) mengemukakan pendapat di diskusi online. Selain itu obserbasi juga dilakukan pada hasil belajar, kendala tindakan yang ditemui, dan persoalan lain yang hadir.

Refleksi adalah aktivitas mengingat dan merenungkan kembali tindakan yang telah dilakukan seperti yang telah dituliskan pada observasi. Refleksi dilakukan di setiap akhir siklus untuk memahami kekuatan dan kelemahan tindakan yang telah dilakukan dan selanjutnya dijadikan acuan untuk memperbaiki dan menyempurnakan tindakan di siklus berikutnya.

Teknik yang digunakan dalam mengumpulkan data kegiatan ini adalah: observasi dan tes hasil belajar, serta catatan lapangan. Observasi digunakan untuk memotret secara rinci aktivitas belajar dengan cara menceklist pilihan yang tersedia pada lembar observasi. Tes hasil belajar dilakukan untuk mendapatkan deskripsi pemahaman murid terhadap materi pelajaran kimia. Dalam hal ini menggunakan instrumen penilaian yang dikembangkan oleh peneliti. Tes hasil belajar dilakukan di akhir setiap siklus dengan menggunakan soal bentuk pilihan ganda. Aspek pembelajaran, suasana kelas, pengelolaan kelas, interaksi pendidik dengan murid, interaksi murid dengan murid, dan beberapa aspek lainnya adalah hal-hal yang dapat digunakan sebagai sumber data pada catatan lapangan di kegiatan ini yang sudah dirancang oleh pendidik atau mitra pendidik.

Data yang dihimpun di kegiatan pengamatan dari implementasi setiap siklus penelitian dianalisis untuk mengetahui kecenderungan yang terjadi. Analisis kualitatif dilakukan pada data yang berupa informasi berbentuk kalimat yang memberi deskripsi tentang ekspresi murid selama proses belajar dalam hal ini adalah hasil data aktivitas murid dan catatan lapangan. Sedangkan analisis kuantitatif adalah analisis yang dilakukan pada data yang berupa angka. Pada penelitian ini analisis kuantitatif dilakukan terhadap tes hasil belajar yang diperoleh murid di setiap siklus tindakan. Data hasil tes berupa hasil belajar dikaji untuk menetapkan nilai rata-rata, ketuntasan belajar secara klasikal, dan kriteria ketuntasan belajar.

\section{HASIL DAN PEMBAHASAN}

Hasil observasi awal pada murid kelas XII MIA 1 SMAN 7 Bulukumba saat pembelajaran daring sebelumnya diperoleh gambaran bahwa aktivitas murid seperti: mengamati demonstrasi guru dan mendengarkan penjelasan guru dengan seksama masih berkategori cukup, sedangkan aktivitas belajar, mengerjakan kuis daring, mengajukan pertanyaan, menyelesaikan tugas dan mengemukakan pikiriannya di diskusi daring masih berpredikat kurang. Hal itu dapat dilihat di Tabel 2. 
Tabel 2. Aktivitas murid di prasiklus

\begin{tabular}{clcc}
\hline No & \multicolumn{1}{c}{ Aktivitas Murid } & Siklus I & Kategori \\
\hline 1 & Mengamati demontrasi guru & $51,5 \%$ & Kurang \\
2 & Mengerjakan kuis & $47,5 \%$ & Kurang \\
3 & Mengajukan pertanyaan & $43,00 \%$ & Kurang \\
4 & Menyimka penjelasan pendidik dengan baik & $55,75 \%$ & Cukup \\
5 & Menyelesaikan tugas secara daring & $36,50 \%$ & Sangat Kurang \\
6 & Mengemukakan pendapat di forum diskusi online & $36,50 \%$ & Sangat Kurang \\
7 & Melakukan eksperimen dengan benar & $43,00 \%$ & Kurang \\
8 & Memaparkan hasil percobaan. & $34,75 \%$ & Sangat Kurang \\
\hline & Rerata & $43,56 \%$ & Kurang \\
\hline
\end{tabular}

Berkaitan dengan hasil belajar murid di mata pelajaran kimia masih berpredikat rendah, yakni dengan rerata 53. Dari 25 murid, hanya 15 orang yang tuntas dan yang lainnya tidak tuntas dengan ketuntasan klasikal 60\%, sebagaimana ditampilkan pada Tabel 3.

Tabel 3. Hasil belajar prasiklus

\begin{tabular}{ll}
\hline Data Hasil Belajar & Capaian \\
\hline Total murid yang mengikuti tes & 25 \\
Nilai Tertinggi & 80 \\
Nilai Terendah & 35 \\
Rerata & 67,2 \\
Jumlah murid yang tuntas & 15 \\
Jumlah murid yang tidak tuntas & 10 \\
\hline Ketuntasan Klasikal & $60 \%$ \\
\hline
\end{tabular}

Berdasarkan hasil observasi awal (prasiklus) maka perlu dilakukan tindakan untuk meningkatakan aktivitas dan hasil belajar kimia dengan mengimplementasikan e-learning memakai Google Classroom. Untuk itu maka dibuat rancangan tindakan berikut ini: (a) melakukan kaijan kurikulum untuk memahami kompetensi dasar yang akan diberikan kepada murid di pembelajaran; (b) menyusun rencana pelaksanaan pembelajaran dengan memperhitungkan waktu yang tersedia; (c) menyiapkan dan mengunggah infografis, modul, dan video pembelajaran, serta LKS; (d) membuat kuis daring; (e) menyiapkan tutorial belajar menggunakan Google Classroom; $(f)$ menyusun instrumen penilaian hasil belajar siklus I; ( $\mathrm{g}$ ) menetapkan fokus pengamatan dan hal-hal yang diamati; (h) membuat pedoman observasi keterlaksanaan pembelajaran; (i) menetapkan sasaran, alat bantu observasi dan cara pelaksanaannya; serta (j) menyiapkan lembar catatan lapangan.

Sebelum pembelajaran dimulai, pendidik menerangkan tentang aplikasi Google Classroom yang akan dipakai dalam menunjang proses belajar mengajar kimia (daring sinkron) melalui aplikasi platform zoom/google meet. Setelah semua murid bergabung di Google Classroom, guru melaksanakan pembelajaran. Pelaksanaan proses belajar mengajar di siklus I dilakukan dalam empat kali pertemuan dengan tahap-tahap yang digambarkan di Tabel 4.

Observasi yang dilakukan di siklus I menggambarkan bahwa aktivitas murid di proses belajar mengajar seperti mengerjakan kuis secara daring sudah berkategori baik. Aktivitas murid yang lain seperti: mengamati demontrasi guru, menyampaikan pertanyaan, menyimak penjelasan pendidik dengan baik, serta menyampaikan pendapat di forum diskusi masih berkategori cukup. Aktivitas mengerjakan tugas dan melakukan percobaan dengan benar masih berkategori kurang. Secara umum aktivitas murid di proses belajar mengajar mempunyai nilai rerata 62,09\% dengan berpredikat cukup dan belum mencapai indikator keberhasilan tindakan yang dirancang. Hasilnya dapat dilihat di Tabel 5 . 
Tabel 4. Langkah-langkah aktivitas proses belajar mengajar siklus I

\section{\begin{tabular}{lll} 
No & $\begin{array}{l}\text { Tahapan } \\
\text { Pembelajaran }\end{array} \quad$ Kegiatan Pembelajaran \\
\hline
\end{tabular}}

Dengan aplikasi google meet, pendidik memulai pelajaran dengan menyampaikan

1 Pendahuluan salam, berdoa, dan melakukan presensi murid serta menerangkan skenario proses belajar mengajar yang akan dilakukan untuk mencapai kompetensi dasar yang telah ditetapkan.

Fase 1: Orientasi murid pada masalah. Guru meminta murid untuk membaca materi pada modul/buku paket yang ditampilkan untuk menemukan persoalan yang berkaitan dengan materi pokok yang diajarkan.

Fase 2: Mengatur murid untuk belajar. Pendidik menghimpun murid di kelompok diskusi secara daring. Murid diarahkan untuk saling berdiskusi untuk memecahkan persoalan yang dirumuskan dengan grup whats'app (daring sinkron).

Fase 3: Melakukan pembimbingan penyelidikan individu maupun kelompok. Dengan menu yang terdapat di aplikasi Google Classroom, murid menjelajahi informasi untuk memecahkan hal yang telah diajukan (daring asinkron). Pendidik membimbing murid saat melakukan penyelidikan dengan kelompok- kelompok diskusi via group whats'app yang telah dibentuk (daring sinkron).

Fase 4: Mengembangkan penyajian hasil karya. Murid dan timnya memecahkan hal yang berhubungan dengan yang diajukan dan berdiskusi secara daring dengan group whats'app masing-masing. Setelah menjelajahi informasi di aplikasi Google Classroom. Dengan masing-masing grup whatsapp, pendidik mengarahkan murid untuk mengkreasikan media tayang yang akan disampaikan di fase proses belajar mengajar setelah ini.

Fase 5: Menganalisis dan mengevaluasi proses pemecahan. Melalui aplikasi zoom/ google meet, pendidik meminta murid untuk menyampaikan hasil diskusi kelompok melalui presentasi secara bergantian. Pendidik mengarahkan murid untuk merefleksi dan mengevaluasi aktivitas yang telah mereka alami. secara daring dengan aplikasi Google Classroom.

Tabel 5. Aktivitas murid siklus I

\begin{tabular}{|c|c|c|c|}
\hline No & Aktivitas Murid & Siklus I & Kategori \\
\hline 1 & Mengamati demontrasi guru & $63,75 \%$ & Cukup \\
\hline 2 & Mengerjakan kuis & $71,00 \%$ & Baik \\
\hline 3 & Mengajukan pertanyaan & $65,00 \%$ & Cukup \\
\hline 4 & Mendengarkan penjelasan guru dengan seksama & $66,25 \%$ & Cukup \\
\hline 5 & Mengerjakan tugas secara & $53,50 \%$ & Kurang \\
\hline 6 & Mengemukakan pendapat pada forum diskusi on-line & $63,75 \%$ & Cukup \\
\hline 7 & Melakukan percobaan dengan benar & $53,50 \%$ & Kurang \\
\hline \multirow[t]{2}{*}{8} & Mempresentasikan hasil percobaan. & $60,00 \%$ & Cukup \\
\hline & Rerata & $62,09 \%$ & Cukup \\
\hline
\end{tabular}


Tes hasil belajar yang dilakukan pada akhir siklus I didapatkan deskripsi bahwa dari 25 murid yang menyelesaikan tes hasil belajar, 17 diantaranya tuntas dan masih ada 8 yang belum tuntas. Rerata skor perolehan murid adalah 74,6 dan ketuntasan klasikal 68\% sebagaimana ditampilkan di Tabel 6.

Tabel 6. Hasil belajar siklus I

\begin{tabular}{lc}
\hline \multicolumn{1}{c}{ Data Hasil Belajar } & Siklus I \\
\hline Total murid yang menyelesaikan tes & 25 \\
Nilai Tertinggi & 90 \\
Nilai Terendah & 45 \\
Rerata & 72.6 \\
Total murid yang tuntas & 17 \\
Total murid yang tidak tuntas & 8 \\
\hline Ketuntasan Klasikal & $68 \%$ \\
\hline
\end{tabular}

Dari refleksi yang dilakukan di siklus I didapatkan beberapa temuan yang perlu diperbaiki di siklus II, hasilnya terlihat di Tabel 7.

Tabel 7. Hasil refleksi siklus I

\begin{tabular}{|c|c|c|c|}
\hline No & Refleksi & Temuan & Revisi \\
\hline 1 & $\begin{array}{l}\text { Aktivitas } \\
\text { murid }\end{array}$ & $\begin{array}{l}\text { Secara umum aktivitas murid di proses } \\
\text { belajar mengajar masih berpredikat cukup } \\
\text { dan belum memenuhi indikator keberhasilan } \\
\text { tindakan yang dirancang. }\end{array}$ & $\begin{array}{l}\text { Pendidik harus melakukan } \\
\text { pembimbingan yang intesif kepada } \\
\text { seluruh semua murid selama proses } \\
\text { belajar mengajar terjadi. }\end{array}$ \\
\hline 2 & Hasil belajar & $\begin{array}{l}\text { Masih terdapat } 8 \text { orang murid yang belum } \\
\text { tuntas, ketuntasan klasikal masih } 68 \% \text { dan } \\
\text { belum mencapai indikator keberhasilan } \\
\text { yang dirancang. }\end{array}$ & $\begin{array}{l}\text { Guru harus menambah penjelasan } \\
\text { tentang materi pelajaran dan } \\
\text { memastikan semua murid memahami } \\
\text { penjelasan yang diberikan }\end{array}$ \\
\hline 3 & Aktivitas guru & $\begin{array}{l}\text { Komunikasi interaktif antara guru dan murid } \\
\text { belum banyak terlihat dan belum banyak } \\
\text { memberikan motivasi kepada murid selama } \\
\text { proses pembelajaran. }\end{array}$ & $\begin{array}{l}\text { Guru hendaknya melakukan } \\
\text { komunikasi multiarah dengan murid, } \\
\text { selain itu pendidik harus lebih } \\
\text { memberikan motivasi murid saat } \\
\text { proses belajar mengajar terjadi. }\end{array}$ \\
\hline
\end{tabular}

Dari hasil refleksi dan rekomendasi perbaikan tindakan siklus I maka dilakukan rancangan ulang siklus II. Rancangan yang disusun pada haikikatnya sama dengan siklus I, sebagai berikut: (a) menyusun rancangan implementasi proses belajar mengajar dengan memperhitungkan waktu yang tersedia; (b) mengunggah video proses belajar mengajar di awal dan kuis daring di akhir pembelajaran; (c) memberikan lembar kerja peserta didik (LKPD) dan modul yang diunggah sebelum proses belajar mengajar berlangsung; (d) pemberian motivasi kepada murid agar semakin aktif lagi di aktivitas pembelajaran; (e) melakukan bimbingan yang lebih intensif kepada setiap kelompok; $(f)$ merancang instrumen penilaian pemahaman konsep siklus II; $(\mathrm{g})$ menetapkan fokus observasi dan hal-hal yang diobservasi; ( $h$ ) menetapkan pedoman observasi keterlaksanaan pembelajaran; serta (i) menetapkan lembar catatan lapangan.

Implementasi proses belajar mengajar di siklus II dilakukan dalam tiga kali pertemuan seperti yang terlihat di Tabel 8. 
Tabel 8. Tahapan aktivitas proses belajar mengajar siklus II

\begin{tabular}{ll}
\hline No Tahapan Pembelajaran & Kegiatan Pembelajaran \\
\hline & Dengan aplikasi zoom/google meet, pendidik melakukan kegiatan \\
& pembuka dengan menyampaikan salam, berdoa, dan memeriksa murid. \\
& Terdapat seorang murid tidak datang dan tujuh murid yang tidak datang \\
& tepat waktu karena jaringan internet yang tidak mendukung. Pendidik \\
& menerangkan skenario proses belajar mengajar yang akan dilakukan untuk \\
& mencapai kompetensi dasar yang telah ditetapkan. Selanjutnya pendidik \\
& menerangkan secara singkat tujuan proses belajar mengajar yang harus \\
& dipenuhi. Melakukan penelusuran pengetahuan awal murid sebelum \\
& aktivitas proses belajar mengajar dengan memberikan pertanyaan yang \\
& berhubungan dengan materi. Saat diberikan kesempatan menjawab, ada \\
& dua orang murid menunjuk tangan. Pendidik memfasilitasi kedua murid itu \\
& secara berurutan mengemukakannya. Tidak lupa pendidik menyampaikan \\
& apresias kepada kedua murid yang menanggapi pertanyaan pendidik. \\
\hline
\end{tabular}

Fase 1: Orientasi murid pada masalah. Pendidik mempersilahkan murid untuk menyimak video redoks dan membaca buku paket untuk mencaritahu persoalan yang berhubungan dengan penyetaraan persamaan reaksi redoks (daring sinkron).

Fase 2: Mengorganisasikan murid untuk belajar. Pendidik menghimpun murid pada kelompok diskusi secara daring. Murid difasilitasi untuk saling berdiskusi dan memecahkan persoalan yang ditetapkankan dengan group WhatsApp (daring sinkron).

\begin{tabular}{ll}
\hline & Fase 3: Membimbing penyelidikan individu maupun kelompok. Dengan \\
& adanya menu yang terdapat di aplikasi Google Classroom, murid \\
& menjelajahi informasi untuk memecahkan persoalan yang telah ditetapkan \\
& (daring asinkron). Pendidik membimbing murid saat menyelidiki kelompok- \\
& kelompok diskusi via grup whatsapp yang telah dibentuk (daring sinkron). \\
& Fase 4: Mengembangkan penyajian hasil karya. Murid dengan kelompoknya \\
& memecahkan persoalan yang berhubungan dengan persoalan yang \\
& ditetapkankan dengan berdiskusi secara daring melalui grup WhatsApp \\
& masing-masing. Sesudah menjelajahi informasi menggunakan aplikasi \\
& Google Classroom dan berdiskusi di masing-masing group WhatsApp, \\
& pendidik memandu murid untuk merancang media tayang yang akan \\
& dilakukan pada fase proses belajar mengajar setelah ini. \\
& Fase 5: Menganalisis dan mengevaluasi proses pemecahan persoalan. \\
& Melalui zoom/google meet, pendidik mengarahkan murid untuk \\
menyampaikan hasil diskusi kelompok melalaui presentasi tiap kelompok. & Pendidik memfasilitasi murid untuk merefleksi dan mengevaluasi aktivitas \\
& yang telah mereka alami (daring sinkron) \\
\hline Dengan aplikasi zoom/google meet, pendidik memfasilitasi murid untuk \\
merancang simpulan. Pendidik juga mengarahkan murid untuk mempelajari \\
materi sesudah ini. Pendidik melakukan kegiatan penutup pelajaran dengan \\
menyampaikan salam dan doa bersama dipandu oleh salah seorang murid. \\
\hline
\end{tabular}

Hasil pengamatan di siklus II yang dilihat di Tabel 9 memperlihatkan bahwa kegiatan murid seperti: menyelesaikan kuis secara daring, menyimak penjelasan pendidik dengan baik, serta menyelesaikan tugas dan melakukan percobaan tergolong sangat baik, sedangkan aktivitas belajar lainnya tergolong baik. Murid mulai terbiasa dengan e-learning menggunakan Google Classroom. Mereka tidak canggung lagi memberikan penjelasan, bertukar pikiran, antusias dalam presentasi dan percaya diri dalam menanggapi pendapat murid/kelompok lain. Secara umum kegiatan murid di siklus II termasuk baik dan telah memenuhi kriteria keberhasilan tindakan. 
Tabel 9. Aktivitas murid siklus II

\begin{tabular}{llll}
\hline No & \multicolumn{1}{c}{ Aktivitas Murid } & Siklus II & \multicolumn{1}{c}{ Kategori } \\
\hline 1 & Mengamati demontrasi guru & $81,25 \%$ & Baik \\
2 & Mengerjakan kuis & $85,50 \%$ & Sangat Baik \\
3 & Mengemukakan pertanyaan & $77,50 \%$ & Baik \\
4 & Mendengarkan penjelasan guru dengan seksama & $85,75 \%$ & Sangat Baik \\
5 & Menyelesaikan tugas secara online & $85,50 \%$ & Sangat Baik \\
6 & Mengemukakan pendapat di forum diskusi on-line & $78,75 \%$ & Baik \\
7 & Melakukan percobaan dengan benar & $85,50 \%$ & Sangat Baik \\
8 & Mempresentasikan hasil percobaan. & $78,75 \%$ & Baik \\
\hline & Rerata & $82,31 \%$ & Baik \\
\hline
\end{tabular}

Hasil tes belajar yang dilakukan di akhir siklus II terdeskripsikan di Tabel 10. Didapatkan bahwa dari 25 murid yang melakukan tes hasil belajar, 22 diantaranya berpredikat tuntas dan terdapat 3 murid yang belum tuntas. Skor terendah perolehan murid adalah 60, skor tertinggi adalah 90, dan rerata adalah 81,2, serta ketuntasan klasikal adalah 88\%. Dapat dijelaskan hasil belajar murid di siklus II sudah mencapai indikator keberhasilan tindakan yang sudah ditetapkan.

Tabel 10. Hasil belajar siklus II

\begin{tabular}{lc}
\hline \multicolumn{1}{c}{ Data Hasil Belajar } & Siklus II \\
\hline Total murid yang melakukan tes & 25 orang \\
Nilai Tertinggi & 90 \\
Nilai Terendah & 60 \\
Rerata & 81,2 \\
Total murid yang tuntas & 22 orang \\
Total murid yang tidak tuntas & 3 orang \\
\hline Ketuntasan Klasikal & $88 \%$ \\
\hline
\end{tabular}

Berdasarkan hasil pengamatan aktivitas belajar, tes hasil belajar, dan catatan lapangan, mendeskripsikan tindakan di siklus II sudah berhasil memperbaiki kekurangan yang ditemukan di siklus sebelumnya. Perbaikan yang dilakukan telah mencapai kriteria keberhasilan penelitian. Oleh karena itu tindakan dirasakan cukup.

Pada proses belajar mengajar, pendidik memiliki makna dalam memegang kendali atau merekayasa suasana proses pembelajaran. Pendidik harus memfasilitasi atau memudahkan proses belajar mengajar contohnya dengan menghadirkan kondisi kegiatan proses belajar mengajar yang kondusif, serasi dengan tumbuh kembang murid, sehingga interaksi belajar mengajar terjadi efektif dan optimal. Hal ini dapat tercipta jika pendidik bisa memanfaatkan media dan metode proses belajar mengajar yang serasi dengan karakter murid.

Pemakaian metode proses belajar mengajar yang sesuai akan lebih mudah menetapkan informasi serta mengatur tahap demi tahap proses belajar mengajar yang akan dilakukan dengan efektif. Proses belajar mengajar akan menjadikan murid sebagai sentral dimana pendidik berperan sebagai fasilitator yang mengatur pembelajaran. Berarti proses belajar mengajar menjadi lebih menarik dan akan mempermudah murid menerima konsep proses belajar mengajar secara langsung, serta menumbuhkan minat dan aktivitas belajar.

Analisis hasil observasi aktivitas murid pada e-learning berbasis Google Classroom, diperoleh gambaran kegiatan murid di proses belajar mengajar meningkat dari rerata 43,56\% sebelum dilakukan tindakan menjadi 68,90\% di siklus I, dan menjadi 81,90\% di akhir siklus II sebagaimana terlihat pada Gambar 2. 


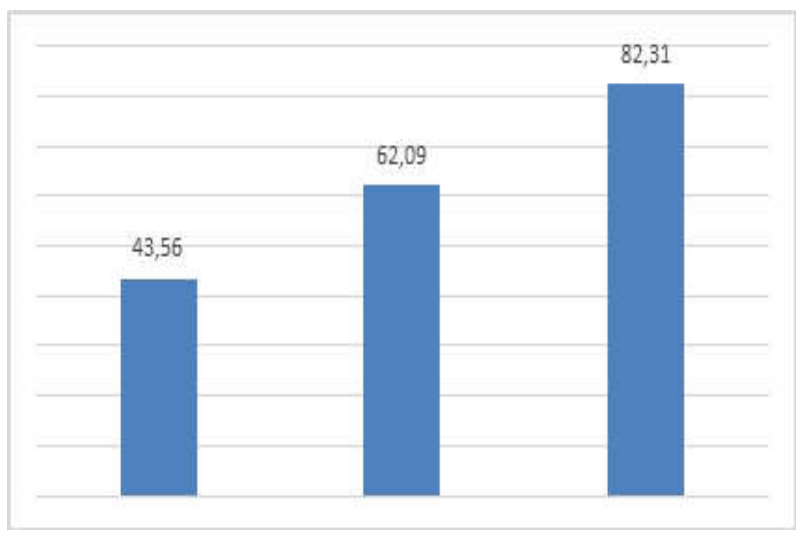

Gambar 2. Perbandingan aktivitas belajar

Beberapa indikator kegiatan belajar di siklus I seperti ditunjukkan di Tabel 5 masih belum memenuhi kriteria ketuntasan minimal. Kegiatan belajar seperti memperhatikan demontrasi pendidik, menyimak penjelasan pendidik dan mengemukakan pertanyaan masih belum mencapai skor maksimal. Hal ini dikarenakan masih kurangnya persiapan murid pada materi yang akan dikuasai. Murid mempunyai ketergantungan yang besar kepada pendidik dalam mendapatkan pengetahuan. Murid tidak berusaha mendapatkan sumber belajar yang lain terutama yang berasal dari internet. Selain itu, murid terlalu mudah merasa puas dengan keterangan pendidik dan secara tidak sadar menjadikan mereka merasa tidak perlu mengemukakan pertanyaan.

Kegiatan belajar lainnya yaitu mengeksperimenkan percobaan dengan benar dan memaparkan hasilnya. Kedua kagiatan ini juga belum memenuhi skor maksimal. Hal ini dikarenakan murid tidak mempersiapkan diri pada materi praktik yang akan dicobakan. Sehingga murid mendapatkan kesukaran saat mengeksperimenkan percobaan dan hasil yang diperolehnya pun tidak maksimal dan akhirnya mereka mengalami kesukaran dalam memaparkan hasilnya. Sebagai evaluasi diri, peran pendidik pada proses belajar mengajar juga belum optimal. Murid belum bisa melakukan kegiatan praktik dengan tepat tanpa diarahkan dan diterangkan sebelumnya.

Kegiatan belajar seperti menyampaikan pertanyaan, menyampaikan pendapat di forum diskusi, dan menyelesaikan tugas secara daring juga masih belum optimal. Hal ini dikarenakan kurang aktifnya murid dalam menggunakan website e-learning. Selain itu karena murid baru sekali ini menggunakan aplikasi Google Classroom. Murid kurang mengerti dalam memakai dan memanfaatkan fitur-fitur di Google Classroom secara keseluruhan. Berdasarkan hal itu ditetapkan beberapa rancangan perbaikan untuk siklus II yakni dengan mempersiapkan bahan ajar yang lebih lengkap dan menarik, menyematkan lembar kerja praktik yang diunggah di Google Classroom sebelum proses belajar mengajar dilakukan serta melakukan pembimbingan individu agar murid aktif menggunakan Google Classroom. Pendidik juga membuatkan tutorial mengeni pemanfaatan fitur Google Classroom sehingga murid tidak akan kesulitan dalam memanfaatkannya.

Kegiatan murid pada proses belajar mengajar di siklus II tergolong baik sebagaimana yang diperlihatkan pada Tabel 9. Murid mulai terbiasa dengan e-learning berbasis Google Classroom. Mereka tidak canggung lagi, memberikan penjelasan, bertukar pikiran, antusias dalam presentase dan percaya diri dalam menanggapi pendapat murid/kelompok lain. Murid aktif melakukan telusur informasi untuk menyelesaikan persoalan yang telah disampaikan. Murid bersama kelompoknya aktif memecahkan persoalan yang diajukan dengan berdiskusi secara daring. Secara umum kegiatan murid di siklus II menjadi meningkat dan telah mencapai kriteria keberhasilan tindakan yang telah ditetapkan.

Pemberian motivasi dan bimbingan yang intensif pada siklus II berpengaruh baik terhadap meningkatnya kegiatan murid di pembelajaran. Hal itu sesuai dengan apa yang disampaikan oleh Uzer Usman (2009) bahwa aktivitas pendidik yang dapat mempengaruhi keaktifan murid diantaranya yakni: (1) menyampaikan motivasi atau menarik perhatian murid sehingga mereka menjadi sentral di aktivitas pembelajaran; (2) memberikan stimulus yang dapat berupa masalah, topik, dan konsep yang akan dipelajari; serta (3) menyampaikan bimbingan/petunjuk kepada murid. 
Meningkatnya aktivitas murid di setiap siklus proses belajar mengajar merupakan salah satu indikator keberhasilan pembelajaran. Besarnya aktivitas murid menjadikan interaksi yang besar pula antara pendidik dengan murid ataupun antarmurid. Hal ini mengakibatkan suasana kelas menjadi segar dan kondusif, masing-masing murid bisa memberikan kemampuannya secara optimal. Aktivitas yang muncul dari murid akan mendorong terciptanya pengetahuan dan keterampilan yang menuju pada peningkatan hasil belajar.

Hasil penelitian ini tidak jauh berbeda dengan penelitian yang sudah dilakukan sebelum ini yang memiliki simpulan bahwa pemakaian aplikasi Google Classroom dapat mengoptimalkan keaktifan belajar dan kedisiplinan siswa dalam mengumpulkan tugas (Sari, 2020).

Sejalan naiknya aktivitas murid dalam pembelajaran, pemahaman murid pada konsep yang dipelajarinya mengalami kenaikan pula. Hasil belajar murid ditemukan meningkat dari nilai rerata 67,2 sebelum dilakukan tindakan, menjadi 72,6 di siklus I dan menjadi 81,2 di siklus II. Ketuntasan klasikal ditemukan meningkat dengan cukup baik, yakni dari $60 \%$ sebelum tindakan menjadi $68 \%$ di siklus I dan 88\% di akhir siklus II, seperti dideskripsikan di Gambar 3.

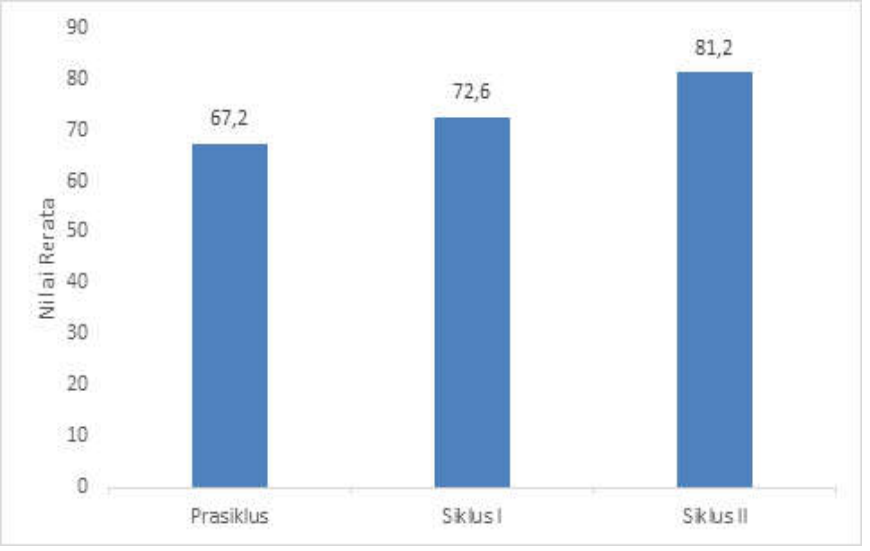

Gambar 3. Perbandingan hasil belajar

Gambar di atas juga menerangkan bahwa perkembangan kognitif adalah suatu proses dimana murid dengan aktif membentuk sistem nilai dan pemahaman pada kenyataan dengan pengalaman dan interaksi mereka di serangkaian kegiatan, misalnya membaca, mengamati, menyimak dan meniru. Belajar akan lebih efektif saat murid melakukannya dengan suasana menyenangkan dan bisa menghayati obyek proses belajar mengajar dengan cara langsung.

Hal ini sesuai dengan penelitian yang sudah dilaksanakan di jenjang SMA (Darmawan, 2019) dan jenjang SMK (Su'uga, 2020), yang menyimpulkan bahwa penggunaan aplikasi dan media daring bisa mengoptimalkan hasil belajar murid di semua tingkatan kelas di semua mata pelajaran.

Dari hasil penelitian ini, melalui pengimplementasian e-learning berbasis Google Classroom dapat mengoptimalkan kegiatan dan hasil belajar kimia di SMAN 7 Bulukumba. Ini pastinya bisa dijadikan penyelesaian kendalayang ditemukan dalam proses belajar mengajar daring di saat pandemi Covid-19 melanda.

\section{SIMPULAN DAN SARAN}

Dari hasil dan pembahasan penelitian tindakan ini bisa disimpulkan bahwa implementasi e-learning memakai Google Classroom pada proses belajar mengajar kimia bisa mengoptimalkan kegiatan belajar murid XII MIA 1 SMAN 7 Bulukumba saat pembelajaran jarak jauh. Ini terdeskripsikan dari kegiatan belajar murid yang terus naik dari memiliki predikat kurang pada sebelum tindakan menjadi berpredikat cukup pada akhir siklus I dan menjadi memiliki predikat baik di akhir siklus II. Penelitian ini juga bisa mengoptimalkan hasil belajar kimia. Hal ini ditemukan dari naiknya hasil belajar dari nilai rerata 67,2 sebelum tindakan menjadi 72,6 di siklus I, dan rerata 81,2 di akhir siklus II. Ketuntasan klasikal juga naik dari $60,0 \%$ sebelum tindakan menjadi $68,0 \%$ di siklus I, dan $88,0 \%$ di akhir siklus II. 
Salah satu kendala dalam menerapkan e-learning berbasis Google Classroom adalah dibutuhkannya penguasaan teknologi komunikasi. Menjadi tantangan bagi pendidik sebagai pemimpin proses belajar mengajar harus bisa beradaptasi dan berinovasi dalam pembelajaran dengan memaksimalkan perangkat teknologi informasi yang terhubung dengan koneksi internet.

\section{PUSTAKA ACUAN}

Darmawan, Y. (2019). Penggunaan Aplikasi Google Classroom dalam Upaya Meningkatakan Hasil Belajar Matematika pada Murid Kelas X IPS 3 SMA Batik 2 Surakarta. Surakarta: Universitas Muhammadiyah.

Kemdikbud. (2020). Surat Edaran Nomor 4 tentang Pelaksanaan Pendidikan dalam Masa Darurat Covid-19. Jakarta: Kemdikbud.

Roycnhansyah, M. S. (2020). Welcoming The New Normal: Transformation of Urban Life. Diskusi Keluarga Alumni Perencanaan Wilayah dan Kota UGM. Yogyakarta: UGM.

Sari, V. K. (2020). Penggunaan Aplikasi Google Classroom untuk Meningkatkan Keaktifan Belajar dan Kedisplinan Pengumpulan Tugas pada Murid Kelas IVB di SDN Godean 1. Prociding Pendidikan Profesi Guru. Yogyakarta: FKIP Universitas Ahmad Dahlan.

Stephen Kemmis, R. M. (2013). The Action Research Planner: Doing Critical Participatory Action Research. Berlin, Heidelberg: Springer.

Su'uga, H. S. (2020). Media E-Learning Berbasis Google Classroom untuk Meningkatkan Hasil Belajar Murid SMK. Jurnal Pendidikan Teknik Elektro, 605-610. 